\title{
Foliar Application of Boron to Almond Trees Affects Pollen Quality
}

\author{
A.M.S. Nyomora, ${ }^{1}$ P.H. Brown, ${ }^{2}$ K. Pinney, ${ }^{3}$ and V.S. Polito ${ }^{4}$ \\ Department of Pomology, University of California, Davis CA 95616
}

\begin{abstract}
AdDitional INDEX wORDs. Prunus dulcis, pollination, fertilization, pollen germination
Abstract. The effect of boron (B) on in vivo and in vitro development of almond [Prunus dulcis (Mill.) D.A. Webb (syn. $P$. amygdalus Batsch)] pollen and pollen tubes and the resultant effect on fruit set was studied in mature trees. The cultivars Mono (pistil donor) and Butte (pollinizer) in an orchard with low soil B in Fresno, California were sprayed with B at $0,0.8,1.7$, or $2.5 \mathrm{~kg} \cdot \mathrm{ha}^{-1}$ during Fall 1993. Pollen viability as indicated by the fluorescein diacetate method (FDA) was $>85 \%$ and was not affected by field-applied $B$, however, in vivo pollen germination and tube growth were enhanced by foliar-applied B. More effect of applied B on in vivo growth appeared as pollen tubes progressed toward the ovary. For in vitro germination, foliar-applied $B$ reduced bursting of tubes, and addition of $B$ to the culture media significantly increased pollen germination and pollen tube growth.
\end{abstract}

Most commercial almond [Prunus dulcis (syn. P. amygdalus)] cultivars are self-unfruitful (Griggs 1953) and therefore need to be interplanted with cross-compatible, pollinizer cultivars to produce an appreciable crop (Hill et al., 1985). Important factors that a grower must consider when selecting cultivar and pollinizer combinations include bloom overlap and the capacity to produce pollen in sufficient quantity and quality. While genetic factors determine the ultimate potential of the pollinizer (Hill et al., 1985), environmental variables, including mineral nutrition of the plant, can influence the quantity and quality of the pollen produced and its subsequent performance.

In some Prunus sp., including almond, the presence of pollen tubes in the transmitting tissue activates the final phases of ovule and megagametophyte development that lead to ovule receptivity (Herrero and Arbeloa, 1989; Pimienta and Polito, 1983). In almond, pollen tubes arrive at the obturator and there is a temporary cessation of their growth at this point. While pollen tube growth is arrested at the obturator, megagametophyte development is completed. Pollen tube growth resumes after megagametophyte differentiation is complete (Pimienta and Polito, 1983).

Williams (1965) introduced the term effective pollination period (EPP) to describe the window of time during which pollination may result in fertilization. EPP incorporates stigma receptivity, ovule longevity and the time needed for pollen tubes to reach the ovule, i.e., the rate of pollen tube growth. Research leading to yield models by Brain and Landsberg (1981) in apple [Malus sylvestris (L.) Mill. var domestica (Borkh.) Mansf.], and DeGrandi-Hoffman (1989) in almond shows that fruit set is determined by the number of flowers per tree and EPP. In these models, the time taken by pollen tubes to reach the ovule is a primary attribute used to calculate predicted yields. In view of these relationships, optimal orchard management practices in a species such as almond, where maximum fruit set is desired, should aim at extending EPP to maximize fertilization success.

Received for publication 19 Apr. 1999. Accepted for publication 8 Dec. 1999. This research was supported by USDA National Research Initiative grant 9801010 to P.H.B.The cost of publishing this paper was defrayed in part by the payment of page charges. Under postal regulations, this paper therefore must be hereby marked advertisement solely to indicate this fact.

${ }^{1}$ Research scientist, Ministry of Agriculture and Cooperatives, Uyole, P.O. Box 400. Mbeya, Tanzania.

${ }^{2}$ Associate professor. To whom correspondence should be addressed; e-mail: phbrown@ucdavis.edu.

${ }^{3}$ Research associate.

${ }^{4}$ Professor.
One of the ways this can be accomplished is by increasing pollen tube growth rate.

Floral tissues have a relatively higher B content than vegetative tissues (Hanson et al., 1985; Peter and Stanley, 1974; Robbertse et al., 1990; Stanley and Linskens, 1974; Vasil, 1963). This suggests a specific, but yet undetermined, biological function of $\mathrm{B}$ in the reproductive phases of plants. The $\mathrm{B}$ requirement for normal pollen germination and tube growth has been well documented for in vitro cultures (Brewbaker and Kwach, 1963; Kumar and Hecht, 1969; Mascarenhas and Machilis, 1962, 1963; Robbertse et al., 1990). Much less is known regarding the effects of $\mathrm{B}$ on pollen tube growth in vivo or on fertilization, where interactions between the pollen tubes and transmitting tissue of the female sporophyte play a role in developmental events. However, under certain field conditions, foliar B applications have been shown to increase fruit set by as much as $100 \%$ (Hanson, 1991a, 1991b) or greater (Nyomora et al. 1997, 1999).

The study described here compliments a study conducted in this same orchard, in which B application to open-pollinated trees resulted in significant yield increases (Nyomora et al., 1997). In contrast to the study reported previously, the present study, addresses issues of in vivo and in vitro pollen germination and growth, and the effects of B treatments on subsequent fruit set. This was achieved by using reciprocal hand pollinations of mature almond trees treated with a range of foliar-applied B applications.

Historically, B recommendations for Californian almond production were based solely on application rates required to B deficiency that resulted in visual leaf symptomology. Evidence that B applications in excess of those required to maximize vegetative growth, can significantly increase yields, was presented in two previous publications (Nyomora et al., 1997, 1999). Foliar B application during fall or spring, is now widely practiced in almonds throughout California (see Nyomora et al. 1999 and references therein). In this current study we provide information on the reproductive and physiological basis of the response of almond to foliar B application.

\section{Materials and Methods}

An orchard having incipient B deficiency (reduced productivity, flower and fruitlet drop but with no vegetative signs of B deficiency) was identified in Fresno County, Calif., in 1992. The presence of incipient $\mathrm{B}$ deficiency in these trees was verified in a 
companion study conducted in this orchard in 1992 and 1993. In 1993, leaf B concentrations in these trees were $21 \pm 1.2$ and 28.6 $\pm 6 \mathrm{mg} \cdot \mathrm{kg}^{-1}$ dry weight in Butte, and Mono respectively (see Nyomora et al. 1997). Rows of 15-year-old 'Ruby', 'Butte', and 'Mono' almond alternated in this orchard. The study described herein was conducted in 1993 in trees adjacent to those described in Nyomora et al. (1997); further details of tree B status and information on tree response to foliar B can be found in this companion paper. The trees used in this current experiment had not previously received soil or foliar $\mathrm{B}$ fertilization.

Solubor $\left(\mathrm{Na}_{2} \mathrm{~B}_{8} \mathrm{O}_{13} \bullet 4 \mathrm{H}_{2} \mathrm{O}\right)$, a commercial product (U.S. Borax, Boron Calif.) containing $20.5 \% \mathrm{~B}$, was applied as a foliar spray 4 weeks after harvest in September, 1993 at a B rate of 0, 0.8, 1.7 or $2.5 \mathrm{~kg} \cdot \mathrm{ha}^{-1}$ (corresponding to B in solution at $0,245,490$ or 735 $\mathrm{mg} \cdot \mathrm{L}^{-1}$ ) to the cross-compatible almond cultivars Butte (pollinizer) and Mono (pistil donor) using a handgun operated sprayer. Each tree was sprayed to drip ( $\approx 15.2 \mathrm{~L}$ of spray solution per tree). Treatments were applied to a block of three adjacent trees and each block was replicated five times. A total of 60 trees per cultivar were used (five blocks $\times$ three replicate trees $\times$ four treatments). Treatments were arranged in a randomized complete block design. Unless otherwise specified, all samplings and determinations were made in Spring 1994.

Hand POllination AND FRUIT SET Determination. Twenty healthy branches on five replicate trees (one from each block for each treatment) of the treated pistil donor trees were selected and bagged at the popcorn stage of budbreak to prevent insect interference in the controlled pollination. Before flower opening (late popcorn stage), pollen was harvested from treated and nontreated pollen donor trees and processed in the laboratory and stored at $20{ }^{\circ} \mathrm{C}$ in sealed freezer bags (Galleta, 1983) until used for subsequent experiments. When the flowers opened and stigmas on pistil donor trees were receptive, $\approx 30$ flowers in each bag were hand pollinated using a fine camel-hair brush. The bags were replaced after pollination. Pollen from each pollinizer treatment was applied to flowers on five bagged branches per tree.

Fruit set was determined by counting all cross-pollinated flowers $(\approx 30)$ on each bagged branch $(20)$, in each replication $(5)$, and treatment (4). Flowers were counted in February 1994, remaining flowers and fruitlets were then counted in March and again in June. Fruit set was determined as percentage fruit remaining at each stage and data were corrected for initial flower count and pistils removed for other purposes (see below).

IN VIVO POLLEN GERMINATION AND GROWTH. In vivo pollen tube growth was assessed according to Kho and Baer (1968) and O'Brien and McCully (1981) with some modifications. Ten pollinated pistils from each treated pistil donor tree (two pistils per bagged branch) were harvested every $24 \mathrm{~h}$ for $7 \mathrm{~d}$, and fixed in $25 \mathrm{~mL} 75 \%$ ethanol. They were rinsed in deionized water, then transferred to $0.8 \mathrm{~mol} \cdot \mathrm{L}^{-1} \mathrm{NaOH}$ overnight to soften and clear the tissue. Softened pistils were rinsed three times in double-deionized water, tapped dry on blotting paper, and incubated in a solution containing $0.005 \%$ aniline blue (Polysciences, St. Louis, Mo.), $0.15 \mathrm{~mol} \cdot \mathrm{L}^{-1} \mathrm{~K}_{3} \mathrm{PO}_{4}$, and $65 \%$ sucrose. The stained pistils were placed on slides under cover slips and squashed gently in the stain solution. Pollen tubes were viewed using a Leitz Diaplan fluorescent microscope (Wetzlar, Germany) with a 100-W Hg lamp and Leitz filter block $\mathrm{G}$ to provide near-ultraviolet excitation. Tubes fluoresced a bright greenish yellow indicative of callose (1, 3 ß-glucan). For each treatment replicate and harvest time, 10 pistils were scored for the total number of pollen tubes in the upper third of the transmitting tissue, their lengths, the length of the style penetrated, and the number of tubes reaching the base of the ovary. Pollen tube length was measured using an ocular micrometer. A total of 4000 pistils were observed.

In VITRO POLLEN GERMinATION AND GROWTH. Pollen viability was determined by the fluorescein diacetate (FDA) method described by Heslop-Harrison and Heslop-Harrison (1970). Pollen was hydrated by incubation at $100 \%$ relative humidity for 30 min. Hydrated pollen was then incubated on slides in a freshly prepared staining solution prepared by adding FDA at $2 \mathrm{mg} \cdot \mathrm{mL}^{-}$ ${ }^{1}$ in acetone stock solution, drop by drop to water until flocculation. The slides were observed under a fluorescence microscope (excitation wavelength $\approx 450$ to $490 \mathrm{~nm}$; emission wavelength $\approx 550$ to $560 \mathrm{~nm}$ ). Viable pollen fluoresced bright yellow green and nonviable pollen grains did not fluoresce. Pollen viability was calculated as the percentage of pollen grains that fluoresced.

Pollen harvested from pollen-donor trees were hydrated as above and incubated at $20^{\circ} \mathrm{C}$ in petri plates on a medium containing $15 \%$ sucrose, $1 \%$ agar with or without $\mathrm{B}$ at $100 \mathrm{mg} \cdot \mathrm{L}^{-1}$, and adjusted to $\mathrm{pH}$ 5.8. Pollen germination was recorded after $1 \mathrm{~h}$ of incubation as the percentage of germinated pollen in a total of 100 grains from different areas of the petri plate. Pollen was considered to have germinated if the pollen tube was twice as long as the diameter of the pollen grain. Each pollen sample was replicated twice. Percentage data were subjected to arcsine transformation before statistical analysis.

Pollen was germinated as above using incubation periods of 1 , 2 , and $3 \mathrm{~h}$. Length was measured on 100 tubes and for this we used a digitizer tablet interfaced to a microcomputer (Polito, 1983). The tablet cursor was fitted with a light-emitting diode (LED) whose image was projected through a drawing tube attachment into the binocular head of a compound microscope, where it was visible as a small dot superimposed on the microscope image. Pollen tubes were traced with the image of the LED and tube length was determined by computer analysis of the digitized points.

Data were analyzed using Statview and Superanova statistical analysis software (Abacus concepts, Berkeley, Calif.). Analysis of variance and protected least squares differences were used for mean separation. For all determinations, a significant pistil-B by pollen-B interaction was observed.

\section{Results}

IN VIVO GERMINATION AND POLLEN TUBE GROWTH. MaXimum in vivo germination ( $85 \%$ to $90 \%$ ) $48 \mathrm{~h}$ after B application occurred in pollen harvested from trees that received $\mathrm{B}$ at $0.8 \mathrm{~kg} \cdot \mathrm{ha}^{-1}$ and germinated on styles from trees that received $B$ at 0.8 or $1.7 \mathrm{~kg} \cdot \mathrm{ha}^{-1}$ (Fig 1A). The highest rate of B $\left(2.5 \mathrm{~kg} \cdot \mathrm{ha}^{-1}\right)$, applied either to pollinizer or pistil donor trees, reduced pollen germination to the control (no B) level. Mean pollen tube length after $48 \mathrm{~h}$, followed the same pattern and was greatest where both pollinizer and pistil donor trees had received B at 0.8 or $1.7 \mathrm{~kg} \cdot \mathrm{ha}^{-1}$ (Fig 1B), but was reduced when either parent received $B$ at $2.5 \mathrm{~kg} \cdot \mathrm{ha}^{-1}$. However, at 144 and $166 \mathrm{~h}$, significantly more pollen tubes had reached the ovary base when the pollen was harvested from trees receiving B at $2.5 \mathrm{~kg} \cdot \mathrm{ha}^{-1}$ in the pollinizer and germinated on stigmas of pistillate trees that had received B at $0.8 \mathrm{~kg} \cdot \mathrm{ha}^{-1}$ (Table 1 ).

FruIT SET. Reciprocal crosses between pollinizer and pistil donor trees that received varying rates of B showed higher initial fruit set percentages in comparison to crosses from nontreated trees with the exception of crosses that involved combinations of nontreated trees and trees receiving highest rate of B (Fig. 2A). 

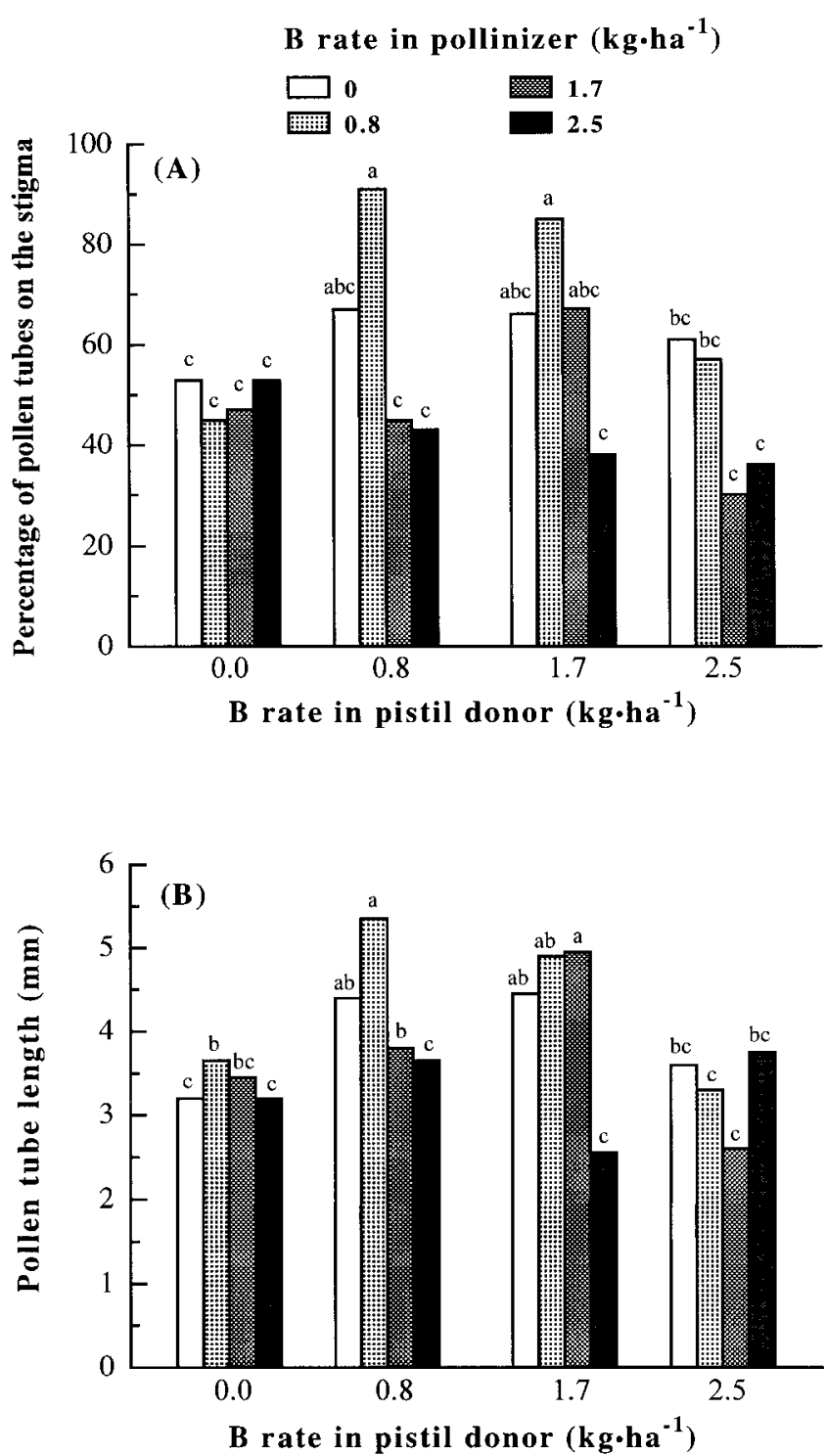

Fig. 1. Effect of foliar B applications to pistil donor and pollinizer trees on (A) percentage pollen germination and (B) pollen tube growth $48 \mathrm{~h}$ after pollination in 'Mono' almond. Means with same letters do not differ significantly $(P>$ 0.05). Legend in $\mathbf{A}$ applies to both figures.

Irrespective of the B treatment in pistil donor trees, pollen from pollinizer trees treated with the control or highest rate of $\mathrm{B}(0$ or $2.5 \mathrm{~kg} \cdot \mathrm{ha}^{-1}$ ) had the lowest initial fruit set. Highest fruit set occurred in the treatment combination in which the pollinizer trees received 0.8 and the pistil donor trees received $\mathrm{B}$ at 0.8 to 1.7 $\mathrm{kg} \cdot \mathrm{ha}^{-1}$. Likewise, B at 0.8 to $1.7 \mathrm{~kg} \cdot \mathrm{ha}^{-1}$ in both tree types gave the highest final set of $60 \%$ to $70 \%$ (Fig. 2B) while pollen from nontreated trees and from trees which had received the highest rate of B resulted in the lowest final fruit set $(40 \%)$.

IN VITRO GERMINATION. Pollen viability, as tested by FDA, was not significantly affected by the foliar-applied B treatments though a nonsignificant trend toward increased viability in pollen from $B$ treated trees was observed (data not presented).

Foliar-applied B resulted in significantly higher in vitro pollen germination (Fig. 3A). Germination percentages ranged from $55 \%$ for pollen from nontreated trees to over $70 \%$ in pollen collected from trees that had received the highest rate of B. Additional B added to the germination medium significantly enhanced pollen germination from a mean of $75 \%$ in pollen collected from trees that had received no $\mathrm{B}$ to $>80 \%$ in pollen from trees that had received foliar $\mathrm{B}$ at $0.8 \mathrm{~kg} \cdot \mathrm{ha}^{-1}$. Addition of $\mathrm{B}$ to the medium resulted in lower germination percentage of pollen harvested from trees sprayed with the higher rate of B (1.7 to 2.5 $\left.\mathrm{kg} \cdot \mathrm{ha}^{-1}\right)$.

Trees that received the highest rate of foliar B produced pollen with a significantly reduced occurrence of burst pollen tubes and pollen tube tip swelling in vitro (Fig. 3B). Additional B in the medium decreased bursting of pollen tubes from nontreated trees and from trees that had received moderate levels of B. However, a slight increase in tube bursting in pollen collected from trees that received the highest rates of $\mathrm{B}$ was observed.

In vitro pollen tube growth results are shown in Fig. 4A and B. Within the first hour of incubation, tubes growing on medium with B were significantly longer than those grown without B in the medium. This growth stimulation was evident in all treatments at each sampling time. The greatest tube length at each incubation time was from pollen harvested from trees that had received $\mathrm{B}$ at $0.8 \mathrm{~kg} \cdot \mathrm{ha}^{-1}$ and germinated on a medium with $\mathrm{B}$. Rates of B at 1.7 and $2.5 \mathrm{~kg} \cdot \mathrm{ha}^{-1}$ applied to trees in the orchard during fall were not effective in promoting pollen tube growth in media with or without $\mathrm{B}$, at any incubation time. Application of $\mathrm{B}$ at $0.8 \mathrm{~kg} \cdot \mathrm{ha}^{-1}$, or the addition of $\mathrm{B}$ to the culture medium, resulted in faster pollen tube growth as indicated by relative pollen tube lengths at 1 and $2 \mathrm{~h}$. At $3 \mathrm{~h}$ the relative benefit of $\mathrm{B}$ at $0.8 \mathrm{~kg} \cdot \mathrm{ha}^{-1}$ or in vitro B applications was diminished.

\section{Discussion}

Benefits of foliar B application to almond have been clearly demonstrated herein and in several recent studies (Nyomora et al., 1997, 1999). In each study, application of B at 0.8 or $1.7 \mathrm{~kg} \cdot \mathrm{ha}^{-1}(245$ or $490 \mathrm{mg} \cdot \mathrm{L}^{-1}$ ) was most effective and increased initial fruit set by $117 \%$ and $13 \%$ and final fruit set by as much as $208 \%$ and $25 \%$ in open pollinated trees of 'Butte' and 'Mono' almond, respectively (Nyomora et al., 1997). This current study aims to investigate further the mechanisms by which $B$ increases fruit set and the role that B plays in reproduction.

Boron application did not affect pollen viability significantly as measured by the FDA method, indicating that pollen from all treatments had high potential germinability. Loss of viability in pollen is thought to involve loss of capacity of the vegetative cell membrane to retain a normal structure on rehydration for osmoregulation (Shivana and Heslop-Harrison, 1981). This capacity is

Table 1 . Number of pollen tubes reaching the ovary base $144 \mathrm{~h}$ after pollination. ${ }^{z}$

B applied

to pistil

donor $\quad$ B applied to pollinizer $\left(\mathrm{kg} \cdot \mathrm{ha}^{-1}\right)$

\begin{tabular}{lllll} 
& \multicolumn{1}{c}{0} & 0.8 & 1.7 & 2.5 \\
\hline 0 & $\left.1.2 \mathrm{~b} \mathrm{~A}^{\mathrm{y}}\right)$ & $1.0 \mathrm{a} \mathrm{A}$ & $3.8 \mathrm{~b} \mathrm{~B}$ & $2.2 \mathrm{~b} \mathrm{~B}$ \\
0.8 & $1.4 \mathrm{~b} \mathrm{~A}^{\mathrm{y}}$ & $0.8 \mathrm{a} \mathrm{A}$ & $3.8 \mathrm{~b} \mathrm{~B}$ & $9.8 \mathrm{c} \mathrm{C}$ \\
1.7 & $1.6 \mathrm{~b} \mathrm{~A}$ & $1.4 \mathrm{a} \mathrm{A}$ & $1.4 \mathrm{a} \mathrm{A}$ & $1.6 \mathrm{a} \mathrm{A}$ \\
2.5 & $0.2 \mathrm{a} \mathrm{A}$ & $1.4 \mathrm{a} \mathrm{B}$ & $1.8 \mathrm{a} \mathrm{B}$ & $3.4 \mathrm{~b} \mathrm{C}$
\end{tabular}

${ }^{\mathrm{z}}$ Values represent the means from five replicate trees, and 10 pistils per observation.

${ }^{\mathrm{y}}$ Mean separation was performed using Fishers protected LSD $(P<0.05)$. Numbers within rows bearing the same upper case letter are not significantly different. Numbers within columns bearing the same lower case letter are not significantly different. 
tested by the fluorescein diacetate method(FDA) (Heslop-Harrison and Heslop-Harrison, 1970) where a positive reaction indicates functional integrity of the vegetative-cell plasma membrane, as well as the presence of esterase activity. Boron has been implicated as having an important role in maintaining plasma membrane integrity (Goldbach et al., 1991), possibly by linking glycoprotein and glycolipid components of the plasma membrane bilayer through its ability to complex OH-containing polysaccharides (Parr and Loughman, 1983, Pilbeam and Kirkby, 1983) or through its involvement in enzyme systems, such as ATPases (Goldbach et al., 1991), or esterases (Shivanna and Heslop-Harrison, 1981), that become active on pollen hydration. In our case, it is possible that pollen was not stored long enough to impart any changes in membrane integrity. Thus, the B treatment showed no effect on membrane integrity. Longer storage times may show a contrary result.

In vivo germination of pollen from trees treated with low to medium rates of $\mathrm{B}$ approached the germinability potential indicated by the FDA test. This observation was confirmed in the field
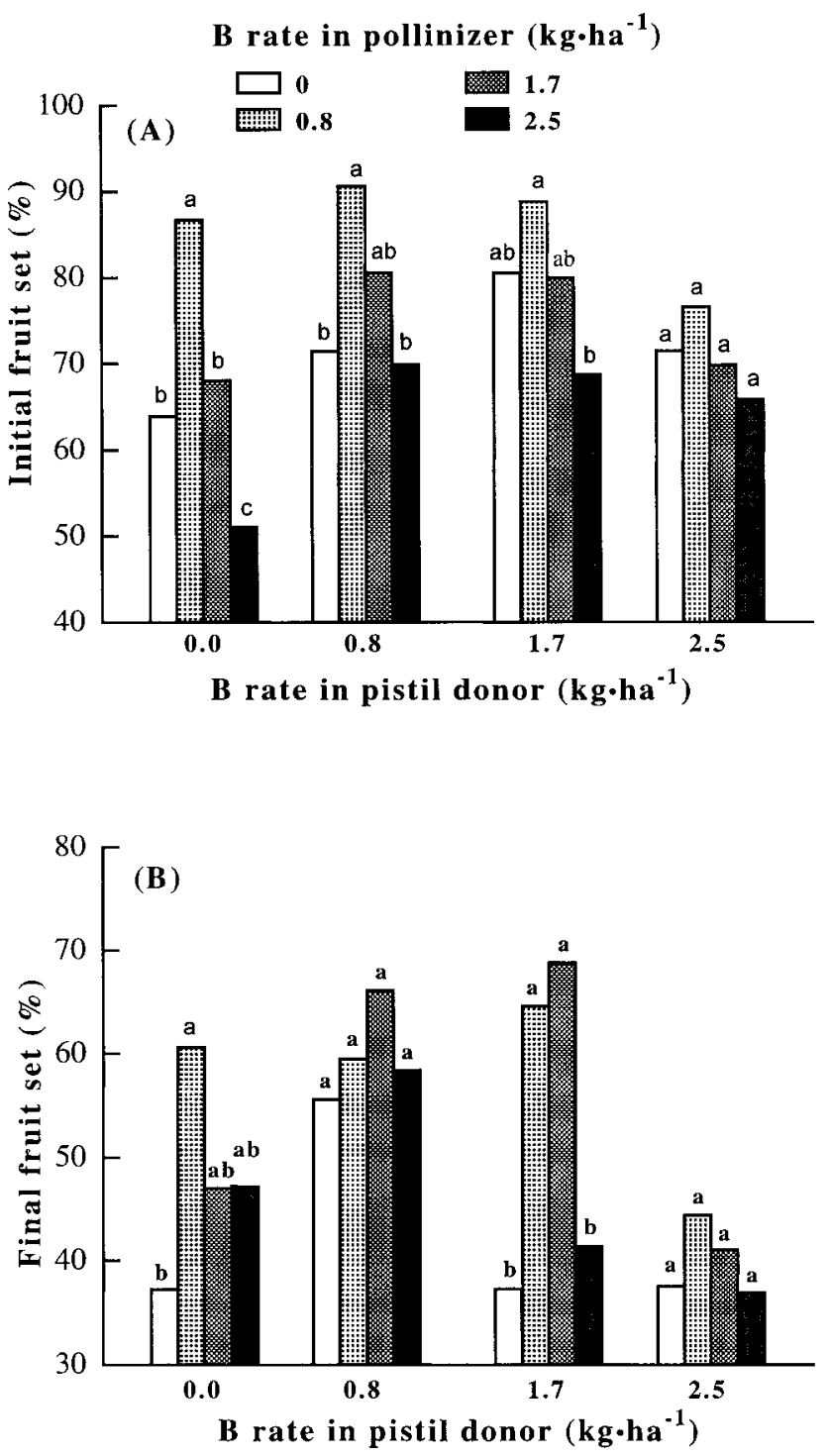

Fig. 2. Effect of foliar B applications to pistil donor and pollinizer trees on 'Mono' almond fruit set following hand pollinations: (A) initial set and (B) final set. Means with same letters do not differ significantly $(P>0.05)$. Legend in $\mathbf{A}$ applies to both figures. by results showing high fruit set from trees treated with low to medium rates of $\mathrm{B}$ obtained from hand pollinations using the same pollen lot.

Treatments that increased pollen germination also seemed to increase pollen tube growth, although the highest B rates (2.5 $\left.\mathrm{kg} \cdot \mathrm{ha}^{-1}\right)$ in either treatment reduced both pollen germination and tube growth to control levels. It appears that moderate levels of B in both pollinizer and pistil donor trees stimulate in vivo pollen germination and subsequent pollen tube growth. This requirement seemed to vary with time as pollen tubes progressed through transmitting tissue. At $48 \mathrm{~h}, \mathrm{~B}$ in the transmitting tissue appeared to be more effective at increasing pollen germination and pollen tube growth. By $144 \mathrm{~h}$ after pollination, the longest pollen tubes were found in treatments using pollen harvested from pollinizer trees that had received the highest $\mathrm{B}$. Pollen tubes reached the ovary after $144 \mathrm{~h}$, which is longer than the $96 \mathrm{~h}$ reported by Pimienta and Polito (1983). This was likely due to the unusually cool and wet weather, which prevailed during bloom in 1994. The highest number of pollen tubes reaching the ovary was from pollen harvested from trees that had received the highest rate of B. In vitro pollen germination suggests that $\mathrm{B}$ at $0.8 \mathrm{~kg} \cdot \mathrm{ha}^{-1}$
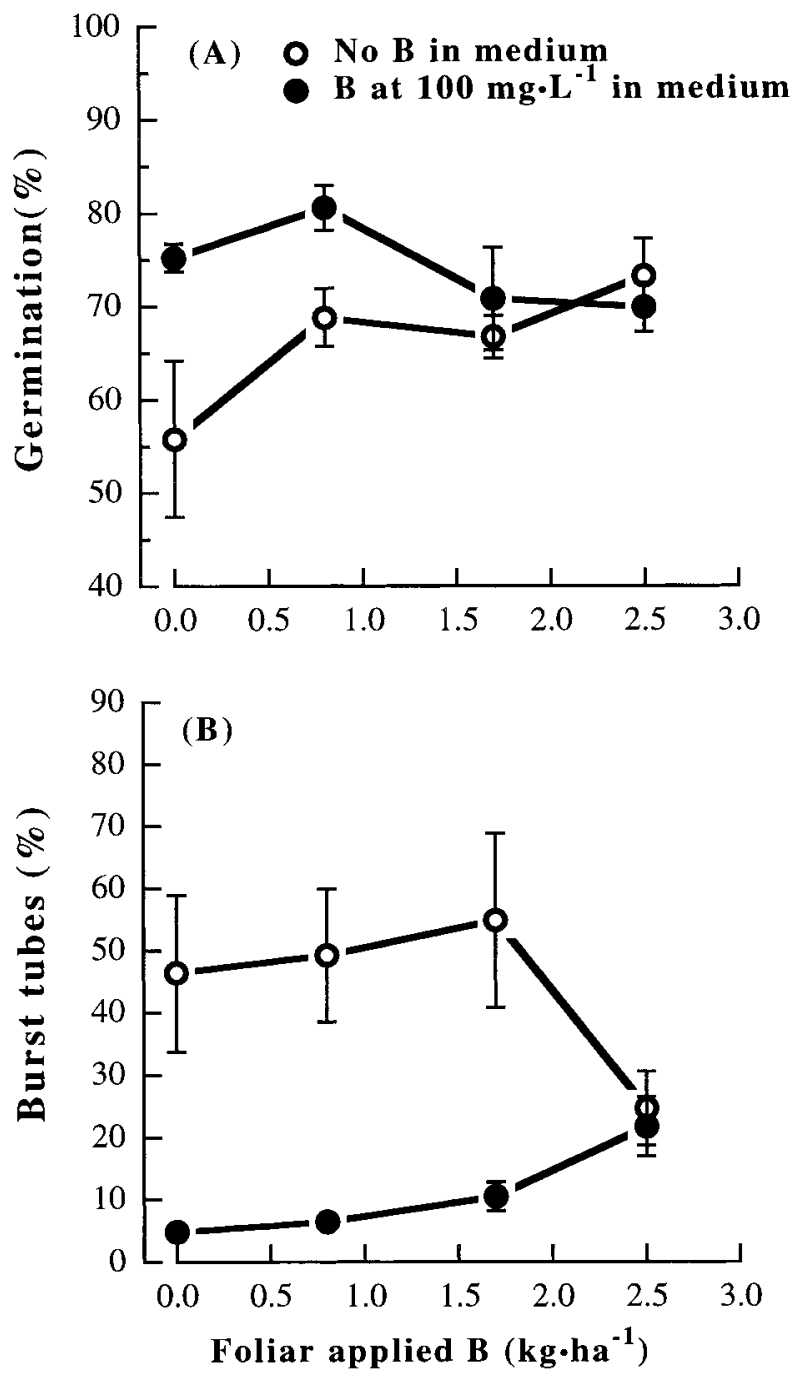

Fig. 3. Effects of foliar applied B and B supplemented media on (A) in vitro pollen germination and (B) tube bursting. Legend in $\mathbf{A}$ applies to both figures. Vertical bars \pm SE. 
resulted in optimal pollen germination and early growth. A role for supplemental B (external to pollen grain B stores) is also suggested by the enhanced in vitro growth of pollen tubes in B supplemented media.

Pollen tubes exhibit tip growth (Steer and Steer, 1989) by fusion of vesicle membranes originating from endoplasmic reticulum and dictyosomes (Jackson, 1991). A possible role for B in pollen tube growth may involve vesicle production, transport, fusion or the subsequent formation of the pollen cell wall. Pollen tube cell wall precursors are rich in polypeptides, mostly glycoprotein (1.5\% to $3 \%$, by weight) and polysaccharides rich in arabino furanosyl residues (Li and Liskens, 1983). Many of these compounds are known to form strong complexes with B (Loomis and Durst, 1992). Most of cell B is known to be located in the cell wall where it is associated with pectinaceous compounds (Hu and Brown, 1994). Under B deficient conditions, cell walls become rigid, inelastic and brittle. In pollen, this could result in decreased tube growth and increased tip bursting. The initial inhibitory effect of high rates of foliar B application ( $\left.2.5 \mathrm{~kg} \cdot \mathrm{ha}^{-1}\right)$ may be due to excessive cross linking of pollen cell walls ( $\mathrm{Hu}$ and Brown, 1994; Loomis and Durst, 1992). With time, tubes grow longer and subsequent complexing of B may have allowed the renewed expansion of the pollen tubes, resulting in their ultimately reaching the ovary.
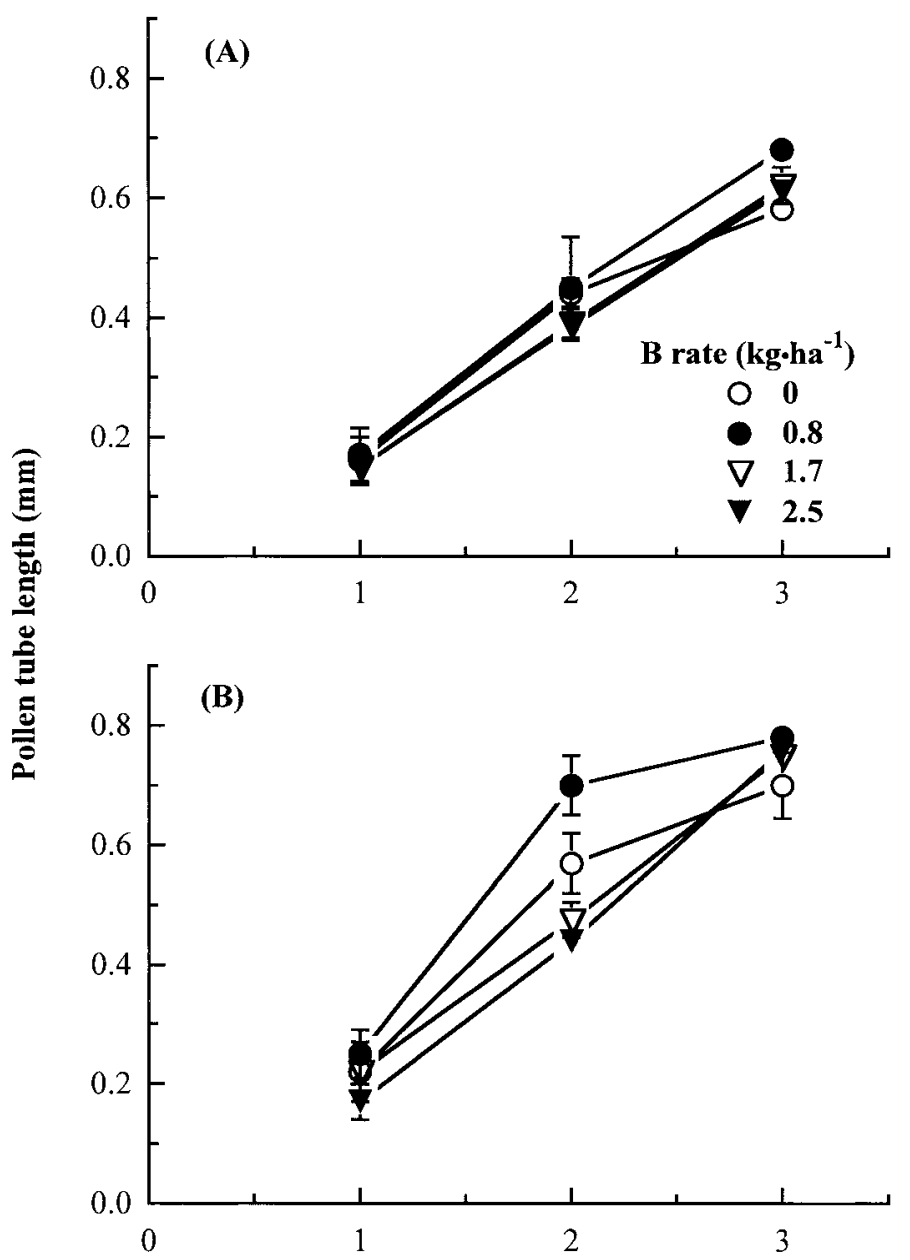

Time in germination (h)

Fig. 4. Pollen tube lengths at 1,2 , and $3 \mathrm{~h}$ after sowing on (A) boron-free germination medium and $(\mathbf{B})$ a medium supplemented with $B$ at $100 \mathrm{mg} \cdot \mathrm{L}^{-1}$. Legend in $\mathbf{A}$ applies to both figures.Vertical bars \pm SE.
In addition to performing a physical role in maintaining cell wall extensibility, B may be involved in carbohydrate or phenolic metabolism which is central to pollen tube growth. Loewus and Labarca (1973) provided evidence that B influences incorporation of D-glucose ${ }^{14} \mathrm{C}$ into pollen tube walls, and may play a crucial role in pollen tube growth. Lewis (1980) suggested that B retards phenol oxidation during pollen tube growth thereby protecting pollen membranes from attack by free radicals generated by phenol oxidation. Degradation of pollen tube membranes would be expected to lead to an increased number of burst tubes that occurred in the B deficient in vitro cultures.

Boron may be involved in some of the biochemical/physiological events involved in pollen germination and tube growth. Kumar and Hecht (1969) found positive correlations between added $\mathrm{B}$ in the medium and increased germination percentage, increased pollen tube length, and increased sugar use. This raises the possibility that B-complexing capability could promote ion and metabolite translocation and transport across biological membranes (Parr and Loughman, 1983; Pollard et al., 1977) to pollen tube wall synthesis site(s). In our experiments, within the first 48 $\mathrm{h}$ of pollination, when B was applied to either of the tree parents, boron in pistil donor trees was significantly more effective than $\mathrm{B}$ applied only to the pollinizer trees. This is in line with findings of Kroh (1973), Kroh and Helsper (1974), and Labarca and Loewus (1973) who, after applying D-glucose- ${ }^{14} \mathrm{C}$ label to lily (Lilium longiflorum L.) pistils, found the label incorporated in pollen tubes.

Low and moderate B applied previously to the trees increased pollen germination and pollen tube growth, respectively. These rates also increased fruit set. These findings are in contrast to results of Callan et al. (1978) on prune (Prunus domestica L.) and De Wet and Robbertse (1989) on mango (Mangifera indica L.). According to these authors, the increases in fruit set that they observed after applying B did not appear to be solely the result of accelerated pollen tube growth rate. It seems that other roles of B not related to pollen tube nutrition and fertilization contribute to the increased fruit set. Callan et al. (1978) speculated that B mediated auxin metabolism to condition the hormone balance in favor of increased fruit set. Increased exogenously applied or endogenous auxin levels (normally kept low by B activity on indoleacetic acid oxidase) stimulates ethylene production which is known to accelerate abscission of leaves, flowers, and fruitlets (Abeles and Rubinstein, 1964). Recently, Lukaszewski and Blevins (1999), suggested that B influences meristematic growth in Arabidopsis thaliana (L.) Heynh. partially through its effect on endogenous auxin metabolism.

Though the B requirement for plant growth has long been recognized, information on the precise role of B in plant metabolism has only recently been determined (for a recent review see Blevins and Lukaszewski, 1998). Boron is now known to play a key role in the extension of plant cell walls through its association with cell-wall pectins and specifically in the formation of rhamnogalaturonan-B dimers (Kaneko et al. 1997; Kobayashi et al., 1996). This documented role of B in cell wall structure is fully consistent with a role for B in pollen germination and growth in which extensive cell wall synthesis and expansive growth is a key process.

A role for B solely in pollen germination and growth, however, does not explain completely the results observed here and elsewhere where it has been demonstrated that B also plays a role in female reproductive organs. We speculate that after accomplishing its role of stimulating pollination and fertilization, $\mathrm{B}$ is 
required for retention of fruitlets, possibly by influencing sink strength of the developing embryo through auxin-mediated events.

\section{Literature Cited}

Abeles, F.B. and B. Rubinstein. 1964. Regulation of ethylene evolution by auxin. Plant Physiol. 39:963-969.

Blevins, D.G. and K.M. Lukaszweski. 1998. Boron in plant structure and function. Annu. Rev. Plant Physiol. Plant Mol. Biol. 49:481-500.

Brain, P. and J.J. Landsberg. 1981. Pollination, initial fruit set and fruit drop in apples: Analysis using mathematical models. J. Hort. Sci. 56:41-54.

Brewbaker, J.L. and B.H. Kwach. 1963. The essential role of calcium ion in pollen germination and pollen tube growth. Amer. J. Bot. 50:747858.

Callan, N.W., M.M. Thompson, and M.N. Westwood. 1978. Effects on fruit set of Italian prune following fall foliar and spring B sprays. J. Amer. Soc. Hort. Sci. 103:253-257.

DeGrandi-Hoffman, G., S.A. Roth, and G.M. Lopper. 1989. ALMOPOL: A cross-pollination and nut set simulation model for almond. J. Amer. Soc. Hort. Sci., 114:170-176.

DeWet, E. and P.J. Robbertse. 1989. The influence of temperature and boron on pollen germination in Mangifera indica. Suud Afrikanse Tydskrift fur Plant und Grond 6:228-234.

Galleta, G.J. 1983. Pollen and seed management, p. 23-47. In: J.M. Moore and J. Janick (eds.). Methods in fruit breeding. Purdue Univ. Press, W. Lafayette, Ind.

Goldbach, H.E., J.B. Grill, N. Lendeman, M. Porzelt, C. Horrmann, B. Lupp, and B. Gessmer. 1991. Influence of boron on net proton release and its relation to other metabolic processes. Current Topics Plant Biochem. Physiol. 10:195-220.

Griggs, W. H. 1953. Pollination requirements of fruit and nuts. Calif. Agr. Expt. Sta. Ext. Serv. Circ. 423.

Hanson, E.J. 1991a. Movement of boron out of tree leaves. HortScience 26:271-273.

Hanson, E.J. 1991b. Boron requirements and mobility in tree species. Current Topics Plant Biochem. Physiol. 10:240-246.

Hanson, E. J., M.H. Chaplin, and P.J. Breen. 1985. Movement of foliar applied boron out of leaves and accumulation in flower buds and flower parts of Italian prune. HortScience 20:747-748.

Herrero, M. and A. Arbeloa. 1989. Influence of the pistil on pollen tube kinetics in peach (Prunus persica). Amer. J. Bot. 76:1441-1447.

Heslop-Harrison, J. and Y. Heslop-Harrison. 1970. Evaluation of pollen viability by enzymatically induced fluorescence: Intercellular hydrolysis of fluorescein diacetate. Stain Technol. 45:115-120.

Hill, S.J., D.W. Stephenson, and B.K. Taylor. 1985. Almond pollination studies: Pollen production and viability, lower emergence and cross pollination tests. Austral. J. Expt. Agr. 25:697-704.

$\mathrm{Hu}, \mathrm{H}$. and P.H. Brown. 1994. Localization of boron in cell walls of squash and tobacco and its association with pectin: Evidence for a structural role of boron in the cell wall. Plant Physiol. 105:681-689.

Jackson, J.F. 1991. Borate control of energy driven protein secretion from pollen and interaction of borate with auxin or herbicide. Current Topics Plant Biochem. Physiol. 10:221-229

Kaneko, S., T. Ishii, and T. Matsunaga. 1997. A boron rhamnogalacturonan II complex from bamboo shoot cell walls. Phytochemistry 44:243-248

Kho, Y. O. and J. Baer. 1968. Observing pollen tubes by means of fluorescence. Euphytica 17:298-302.

Kobayashi, M., T. Matoh, and J. Azuma . 1996. Two chains of rhamnogalacturonan II are cross linked by borate-diol ester bonds in higher plant cell walls. Plant Physiol. 110:1017-1020

Kroh, M. 1973. Nature of intercellular substances of stylar transmitting tissue, p. 195-205. In: F. Loewus (ed.). Proc. Symp. Biogenesis of Plant cell wall polysaccharides. Academic Press, New York.

Kroh, M. and J.P.F.G. Helsper. 1974. Transmitting tissue and pollen tube growth, p. 167-175. In: H.F. Linskens (ed.). Fertilization in higher plants . N-Holland Publ. Co., Amsterdam, The Netherlands.

Kumar, S. and A. Hecht. 1969. Studies on growth and utilization of stylar $\mathrm{CHO}$ by pollen tubes and callose development in self-incompatible Oenothera organogenesis. Biol. Plant. Praha 12:41-46.

Labarca, C. and F. Loewus. 1973. The nutritional role of pistil exudates in pollen tube wall formation in L. longiflorum. II. Production and utilization of exudates from stigma and stylar canal. Plant. Physiol. 52:87-92.

Lewis, D.H. 1980. Are there interrelations between the metabolic role of boron, synthesis of phenolic phytoalexin and the germination of pollen? New Phytol. 84:261-270.

Li, Y. and H.F. Linskens. 1983. Wall bound proteins of pollen tubes after self and cross pollenation. Theor. Appl. Genet. 67:11-16.

Loewus, F. and C. Labarca. 1973. Pistil secretion product and pollen tube wall formation, p. 175-193. In: F. Loewus (ed.). Proc. Symp. biogenesis of plant cell wall polysaccharides. Academic Press, New York.

Loomis, W.D. and R.W. Durst. 1992. Boron and cell walls. Current Topics Plant Biochem. Physiol. 10:149-178.

Lukaszweski, K.M. and D.G. Blevins. 1999. Boron function in IAAdependent growth. Plant Physiol. 119(Suppl.):548.

Mascarenhas, J.P. and L. Machlis. 1962. The hormonal control of the directional growth of pollen tubes. Vitamins Hormones 20:347-370.

Mascarenhas, J.P. and L. Machlis. 1963. Chemotropic response of the pollen of Antirrhinum majus to calcium. Amer. J. Bot. 50:70-77.

Nyomora, A.M.S., P.H. Brown, and M. Freeman. 1997. Fall foliarapplied boron increases tissue boron concentration and nut set of almond. J. Amer. Soc. Hort. Sci. 122:405-410.

Nyomora, A.M.S., P.H. Brown, and B. Krueger. 1999. Rate and time of boron application increase almond productivity and tissue boron concentration. HortScience 34:242-245.

O'Brien, T.P. and M.E. McCully. 1981. The study of plant structure. Principles and selected methods. Thermacarphy Proprietary Ltd., Melbourne, Australia.

Parr, A.J. and B.C. Loughman. 1983. Boron and membrane function in plants, p. 86-103. In: D.A. Robb and W.S. Pierpoint (eds.). Metals and micronutrients: Uptake and utilization by plants. Academic Press, London.

Peter, J.K. and R.G. Stanley. 1974. Boron in pollen and pollen cell fraction, p. 131-136. In: H.F. Linskens (ed.). Fertilization in higher plants. N. Holland Publ. Co., Amsterdam, The Netherlands.

Pilbeam, D.J. and E.A. Kirkby. 1983. The physiology of boron in plants. J. Plant Nutr. 6:563-582.

Pimienta, E. and V.S. Polito. 1983. Embryo sac development in almond, (Prunus dulcis) (Mill). D.A. Webb) as affected by cross-, self-, and non-pollination. Ann. Bot. 51:476-479.

Polito, V.S. 1983. Membrane associated calcium during pollen germination: A microfluorometric analysis. Protoplasma 117:226-232.

Pollard, A.S., A.J. Parr, and B.C. Loughman. 1977. Boron in relation to membrane function in higher plants. J. Expt. Bot. 28:831-841.

Robbertse, P.J., J.J. Lock, E. Stoffeberg, and L.A. Coetzer. 1990. Effects of B on directionality of pollen tube growth in Petunia and Agapanthus. S. Afr. J. Bot. 56:487-492.

Shivanna, K.R. and J. Heslop-Harrison. 1981. Membrane state and pollen viability. Ann. Bot. 47:759-770.

Stanley, R.G. and H.F. Linskens 1974. Boron in pollen and floral organs, p. 307. In: R.G. Stanley, and H.F. Linskens (eds.). Pollen: Biology, biochemistry and management. Springer Verlag, Berlin.

Steer, M.W. and J.M. Steer. 1989. Pollen tube tip growth. New Phytol. 111:323-558

Vasil, J.K. 1963. Effect of B on pollen germination and pollen tube growth, p. 105-110. In: H.F. Linskens (ed.). Pollen physiology and fertilization. N. Holland Publ. Co., Amsterdam, The Netherlands.

Williams, R.R. 1965. The effect of summer nitrogen on the quality of apple blossom. J. Hort. Sci. 40:31-41. 